\title{
Estrogen receptor a polymorphism in boys with constitutional delay of growth and puberty
}

\author{
Byung Ho Kang, MD, \\ So Youn Kim, MD, \\ Mun Suk Park, MS, \\ Kyung Lim Yoon, MD \\ Kye Shik Shim, MD, PhD \\ Department of Pediatrics, \\ Kyung Hee University School of \\ Medicine, Seoul, Korea
}

\begin{abstract}
Purpose: There were a lot of reports regarding associations of polymorphisms in the estrogen receptor a (ESR1). with many disorders. But, those with constitutional delay of growth and puberty (CDGP) are not known. Our aim is to find out any association between CDGP and ESR1.

Methods: In a total of 27 subjects, we compared 7 CDGP patients with 20 healthy controls with their heights and sexual maturity rates were within normal range. We selected three single nucleotide polymorphisms from intron 1 of ESR1 (rs3778609, rs12665044, and rs827421) as candidates, respectively.

Results: In genotype analyses, the frequency of G/G genotype at rs827421 in intron 1 of ESR1 was increased in CDGP boys $(P=0.03)$.

Conclusion: The genetic variation of ESR1 can be a contributing factor of tempo of growth and puberty.
\end{abstract}

Keywords: Eestrogen receptor alpha, polymorphism, single nucleotide, Puberty

\section{Introduction}

Growth and puberty are influenced by genetic and environmental factors. The heritability of growth and puberty is reported about $75-90$ and 50-80\%, respectively. Even though the large proportion of them is affected by genetic factors, but it is difficult to elucidate a major one because of complex polygenic traits ${ }^{1-6)}$.

The boys with constitutional delay of growth and puberty (CDGP) usually have short stature due to slow tempos of growth and are referred to pediatric endocrinologist. But, it may be a challenge to differentiate CDGP from pathologic short stature before onset of puberty, and genetic factors involved in CDGP are not clarified yet ${ }^{7-9)}$.

There were several reports about associations of estrogen receptor a (ESR1) polymorphisms with bone mineral density, breast cancer, height, and age of menarche ${ }^{10-18)}$. Also, the abundant amount of ESR1 is present in epiphyseal plates of long bones ${ }^{19)}$. Therefore, we hypothesized that ESR1 can be a factor that controls the tempo of growth and puberty.

The purpose of this study is to determine whether polymorphisms in ESR1 are associated with CDGP in boys.

\section{Materials and methods}

\section{Subjects}

From July 2008 through August 2012, we recruited 27 boys who visited Kyung Hee University Hospital at Gangdong for growth evaluation. Seven patients diagnosed with CDGP, which is defined as a condition in which the height of individual is at or below the 3rd percentile in the same sex and age group according to the Korean population-based reference $e^{20)}$, annual growth velocity is greater than $4 \mathrm{~cm}$, with delayed puberty and bone age,

Tel: +82-2-440-6131

Fax: $+82-2-440-6295$

E-mail: 64sks@khnmc.or.kr 
but, without evidence of systemic, endocrine, nutritional or chromosomal abnormalities ${ }^{7}$. To differentiate CDGP from hypogonadotropic hypogonadism or hypopituitarism, they underwent combined pituitary function tests ${ }^{8,9)}$. Twenty boys with normal height and pubertal range were grouped as a control.

Height $(\mathrm{cm})$ was measured using standardized equipment (Harpenden stadiometer Ltd., Crymych, UK). The height standard deviation score was calculated by (measured height mean height)/standard deviation. The bone age was assessed by radiographs of the hand and wrist, using a method of Greulich and Pyle ${ }^{21)}$. Midparental target height was calculated by (Father's height $[\mathrm{cm}]+$ Mother's height $[\mathrm{cm}]+13) / 2$ in male.

All subjects and parents provided informed consent before the study commencement. This study was approved by the clinical research ethics committee at Kyung Hee University Institutional Review Board (KHNMC- IRB 2008-019).

\section{Genotyping}

Genomic DNA was isolated from peripheral blood samples of subjects using DNA extraction kit (Qiagen, Venlo, The Netherlands) according to the manufacturer's recommendation. The genomic DNA was amplified with polymerase chain reaction (PCR) with forward and reverse primer pairs and standard PCR reagents in 10 microliter reaction volume, containing $10 \mathrm{ng}$ of genomic DNA, $0.5 \mathrm{pM}$ of each oligonucleotide primer, 1 microliter of 10X PCR buffer, 250 $\mu \mathrm{M}$ dNTP (2.5 mM each) and 0.25 unit Taq DNA Polymerase (5 unit/ $\mu \mathrm{L}$ ) (iNtRON Biotechnology, Seongnam, Korea). The PCR reactions were carried out as follows: 5 minutes at $95^{\circ} \mathrm{C}$ for 1 cycle, and 35 cycles at $95^{\circ} \mathrm{C}$ for 30 seconds, $55^{\circ} \mathrm{C}$ for 30 seconds, $72{ }^{\circ} \mathrm{C}$ for 30 seconds, followed by 1 cycle of $72{ }^{\circ} \mathrm{C}$ for 10 minutes. After amplification, the PCR products were treated with 1 unit each of shrimp alkaline phosphatase (SAP) (USB Co., Cleveland, OH, USA) and exonuclease I (USB Co.) at $37^{\circ} \mathrm{C}$ for 75 minutes and $72{ }^{\circ} \mathrm{C}$ for 15 minutes to purify the amplified products. One microliter of the purified amplification products were added to a ready reaction mixture containing $0.15 \mathrm{pmol}$ of genotyping primer for primer extension reaction. The primer extension reaction was carried out for 25 cycles of $96^{\circ} \mathrm{C}$ for 10 seconds, $50{ }^{\circ} \mathrm{C}$ for 5 seconds, and $60^{\circ} \mathrm{C}$ for 30 seconds. The reaction products were treated with 1 unit of SAP at $37^{\circ} \mathrm{C}$ for 1 hour and $72{ }^{\circ} \mathrm{C}$ for 15 minutes to remove the excess fluorescent dye terminators. One microliter of the final reaction samples containing the extension products were added to 9 microliter of Hi-Di formamide (ABI, Foster City, CA, USA). The mixture was incubated at $95^{\circ} \mathrm{C}$ for 5 minutes, followed by 5 minutes on ice and then analyzed by electrophoresis in ABI Prism 3730xl DNA analyzer. Analysis was carried out using Genemapper ver. 4.0 (Applied Biosystems, Foster City, CA, USA). Table 1 shows the primer sets and Tm used for the reactions.

\section{Statistical analysis}

Statistical analysis was performed using SAS 8.02 (SAS Institute Inc., Cary, NC, USA). The demographic characteristics of the control and patient group were compared with KruskallWallis test. Each result was presented as the mean \pm standard deviation. The value of $P<0.05$ is considered as statistically significant. The frequencies of allele and genotype, and the departures of the genotype distribution from Hardy-Weinberg equilibrium for each single nucleotide polymorphism (SNP) were analyzed using the chi-square test or Fisher exact test. Linkage disequilibrium was calculated with the Haploview ver. 3.2 (Broad Institute, Cambridge, MA, USA). The genotypespecific risks were estimated as the odds ratios with associated 95\% confidence intervals using conditional logistic regression analysis.

\section{Results}

\section{Subjects}

The chronologic age of boys with CDGP is $14.3 \pm 0.5$ years and controls is $14.3 \pm 0.3$ years. The bone age $(12.0 \pm 0.5$ years $)$ was less than chronological age in CDGP patients with significant statistical difference $(P<0.05)$. However, there were no significant differences between bone age $(14.0 \pm 1.0$ years $)$ and chronological age in the control group. Mean height standard deviation score (SDS) in CDGP group was less than that of the control group $(P<0.05)$, but there were no differences in midparental target height SDSs between CDGP and control group. For sexual maturity rates, data showed Tanner stage 1 in CDGP patients and 3 in control group (Table 2). The pituitary function tests were performed in all CDGP patients, and the results were within normal limits (The data was not shown).

\section{Distribution of ESR1 polymorphisms}

Three SNPs were analyzed; rs3778609, rs 12665044 and rs827421 in intron 1 of ESR1. The rs3778609 genotypes were C/C, 42.86\%; C/T, 28.57\%; and T/T, 28.57\% in CDGP patients, and $50.0 \%, 45.0 \%$ and $5.0 \%$ in controls. The rs 12665044

Table 1. Primer sets and Tm for polymerase chain reaction and sequencing reactions

ESR1 (rs3778609): $55^{\circ} \mathrm{C}$

Forward: ATGAGCATATTTTC

Reverse: CTGTCCACATTCTTTGACG

ESR1 (rs12665044): $55^{\circ} \mathrm{C}$

Forward: ATGGCAGATTTGGGAATGTC

Reverse: ATGTAAAGGGTCGGATACAA

ESR1 (rs827421): $55^{\circ} \mathrm{C}$

Forward:TTTTTTAACTTGAGTTTCCCGG

Reverse: TACACCTCATAACAACTAGE

ESR1, estrogen receptor $a$; rs, reference sequence. 
genotypes were C/C, 42.86\%; C/T, 28.57\%; and T/T, 28.57\% in CDGP patients, and $45.0 \%, 45.0 \%$, and $10.0 \%$ in controls. The rs 827421 genotypes were A/A, 14.29\%; G/A, 42.86\%; and; $\mathrm{G} / \mathrm{G}, 42.86 \%$ in CDGP patients, and $35.0 \%, 60.0 \%$, and $5.0 \%$ in controls. Therefore, the frequency of G/G genotype at the rs827421 in intron 1 of ESR1 was increased in CDGP patients with odds ratio of 19.15 ( $P$-value permutation=0.03) (Table 3$)$. In haplotype frequencies, there were no significant differences between cases and controls (Table 4).

\section{Discussion}

CDGP is a condition with short stature due to slow tempo of growth and puberty without any evidence of systemic, endocrine, nutritional, or chromosomal abnormalities. Although the heights of children with CDGP are lower than 3 rd percentile before onset of puberty, their adult heights can be in the range of target height. Therefore, in those children, many

Table 2. Demographic characteristics of subjects

\begin{tabular}{lccc}
\hline Characteristic & Case $(n=7)$ & Control $(n=20)$ & $P$-value \\
\hline Age $(\mathrm{yr})$ & $14.25 \pm 0.50$ & $14.33 \pm 0.33$ & NS \\
Bone age $(\mathrm{yr})$ & $12.00 \pm 0.50$ & $14.00 \pm 1.00$ & $<0.05$ \\
Height $(\mathrm{cm})$ & $145.50 \pm 2.30$ & $156.70 \pm 3.80$ & $<0.05$ \\
Height SDS & $-2.02 \pm 0.38$ & $-0.72 \pm 0.63$ & $<0.05$ \\
MPH $(\mathrm{cm})$ & $170.40 \pm 4.80$ & $172.30 \pm 2.70$ & $\mathrm{NS}$ \\
MPH SDS & $-0.52 \pm 0.80$ & $-0.18 \pm 0.45$ & $\mathrm{NS}$ \\
Testicular size $(\mathrm{mL})$ & $3.00 \pm 0.50$ & $6.00 \pm 1.00$ & $<0.05$ \\
Tanner stage of pubic hair & 1 & 3 & $<0.05$ \\
\hline
\end{tabular}

Values are presented as mean \pm standard deviation.

SDS, standard deviation score; MPH, midparental target height; NS, not significant. interventions and modalities of promoting growth are usually unnecessary $^{1,3)}$.

To differentiate CDGP from other pathologic short stature, for example, subcategory of idiopathic short stature or hypogonadotropic hypogonadism, many studies focused on the genes and hormonal evaluations related with pubertal timing were done $\mathrm{e}^{2,4-7)}$. But, it is a challenge because of similar phenotypes, overlapping of hormonal levels, and still unidentified genetic factors of them ${ }^{7}$.

In aspect of phenotype, the complete discrimination between CDGP and hypogonadotropic hypogonadism may be possible after puberty ${ }^{8)}$. In hormonal studies, basal serum levels of luteinizing hormone, follicle stimulating hormone or inhibin $\mathrm{B}$, stimulation tests with gonadotropin-releasing hormone $(\mathrm{GnRH})$ or agonist and human chorionic gonadotropin were reported to be useful ${ }^{7-9)}$.

The genetic studies about pubertal timing or CDGP are more complicated $^{1,4)}$. Although the inheritance is likely complex, several studies to find out major genes related with them were committed because some predisposing genetic factors have

Table 4. Estimated haplotype frequencies of intron 1 of ESR1 in CDGP cases and controls

\begin{tabular}{lcccc}
\hline Haplotype $^{*}$ & Case (\%) & Control (\%) & OR (95\% Cl) & $\begin{array}{c}\text { P for } \\
\text { interaction }\end{array}$ \\
\hline CCA & $5(35.71)$ & $26(65.0)$ & $0.28(0.08-1.04)$ & 0.06 \\
CCG & $3(21.43)$ & $2(5.0)$ & $4.78(0.68-33.63)$ & 0.12 \\
TTG & $6(42.86)$ & $12(30.0)$ & $2.31(0.62-8.63)$ & 0.21 \\
\hline
\end{tabular}

ESR1, estrogen receptor $a ; C D G P$, constitutional delay of growth and puberty; OR, odds ratio; $\mathrm{Cl}$, confidence interval; SNP, single nucleotide polymorphism; rs, reference sequence.

*ESR1 haplotypes with SNP in intron 1 arranged in the order 5' to 3'; rs3778609, rs12665044, and rs827421.

Table 3. Genotypic and allelic frequencies of the ESR1 in CDGP cases and controls

\begin{tabular}{|c|c|c|c|c|c|}
\hline SNP genotype & Case (\%) & Control (\%) & OR $(95 \% \mathrm{Cl})$ & $P$ for trend & $P$ for permutation \\
\hline rs3778609; 4502C>T & & & & 0.08 & 0.07 \\
\hline CC & $3(42.86)$ & $10(50.0)$ & $1.49(0.24-9.11)$ & & \\
\hline $\mathrm{CT}$ & $2(28.57)$ & $9(45.0)$ & $2.43(0.59-10.0)$ & & \\
\hline $\mathrm{TT}$ & $2(28.57)$ & $1(5.0)$ & $15.49(0.8-299.9)$ & & \\
\hline Callele & $8(57.14)$ & $29(72.5)$ & $2.31(0.62-8.63)$ & & \\
\hline Tallele & $6(42.86)$ & $11(27.5)$ & $1.88(0.54-6.56)$ & & \\
\hline rs12665044; $21187 C>T$ & & & & 0.22 & 0.18 \\
\hline $\mathrm{CC}$ & $3(42.86)$ & $9(45.0)$ & $1.49(0.24-9.11)$ & & \\
\hline $\mathrm{CT}$ & $2(28.57)$ & $9(45.0)$ & $1.83(0.52-6.45)$ & & \\
\hline $\mathrm{TT}$ & $2(28.57)$ & $2(10.0)$ & $5.45(0.45-66.7)$ & & \\
\hline Callele & $8(57.14)$ & $27(67.5)$ & $1.94(0.53-7.08)$ & & \\
\hline Tallele & $6(42.86)$ & $13(32.5)$ & $1.67(0.48-5.81)$ & & \\
\hline rs $827421 ; 28437 A>G$ & & & & 0.01 & 0.03 \\
\hline $\mathrm{AA}$ & $1(14.29)$ & $7(35.0)$ & $4.63(0.42-50.82)$ & & \\
\hline$A G$ & $3(42.86)$ & $12(60.0)$ & $6.49(1.07-39.58)$ & & \\
\hline GG & $3(42.86)$ & $1(5.0)$ & $19.15(1.28-287.17)$ & & \\
\hline A allele & $5(35.71)$ & $26(65.0)$ & $4.1(1.1-15.33)$ & & \\
\hline Gallele & $9(64.29)$ & $14(35.0)$ & $3.6(1.01-12.79)$ & & \\
\hline
\end{tabular}

ESR1, estrogen receptor $a$; CDGP, constitutional delay of growth and puberty; SNP, single nucleotide polymorphism; OR, odds ratio; Cl, confidence interval; rs, reference sequence. 
a dominant effect $^{22)}$. Genome wide association studies are useful method to identify the linkage of polygenic inheritance, and the Early Growth Genetics Consortium in Europe found associations of $L I N 28 B, M A P K 3$, and ADCY3-POMC with pubertal height growth, menarche, body mass index, and early puberty ${ }^{2}$. Also, many candidate genes were studied for a long time.

Banerjee et al. ${ }^{23}$ studied if there is any association of leptin or leptin receptor polymorphism with CDGP, but no association was found, leptin was thought as only a prerequisite factor for puberty. $G n R H$ and GnRH receptor (GnRHR) genes were also strong candidates because puberty begins with GnRH pulse, and Lin et al ${ }^{24)}$ found a homozygous R262Q mutation in GnRHR in two boys with hypogonadotropic hypogonadism from one family. However, Sedlmeyer et al. ${ }^{25)}$ studied and concluded genetic variation in GnRHI and GnRHR was not likely to be a modulator of pubertal timing in general population.

Pugliese-Pires et al. ${ }^{26)}$ reported the cases of CDGP with novel inactivation mutations in the GHSR gene, and he thought abnormalities in ghrelin receptor function may influence the phenotype of CDGP. Kauffman et al. ${ }^{27}$, and Seminara et al. ${ }^{28)}$ studied Kiss 1 and GPR54 as candidate genes in mice. Tommiska et al. ${ }^{29)}$ and Ong et al ${ }^{30)}$ also thought and studied LIN28B as a related gene with obesity and earlier puberty. But, Gajos et al. ${ }^{31)}$ and Vaaralahti et al. ${ }^{32)}$ s studies told us that the gene variants or defects found in hypogonadotropic hypogonadism are not related with CDGP. Finally, it is still a conundrum to deciphering the genetics of pubertal onset, timing, and CDGP. In 2010, Borjesson et al. ${ }^{33)}$ suggested the low concentration of estrogen may be involved in pubertal growth spurt and the interaction of high concentration of it and its receptor (ESRI) can be a factor of epiphyseal plate closure in long bones.

ESR1 is in chromosome 6 and composed of 8 exons in human ${ }^{12)}$. Futhermore, there were several studies regarding the associations of ESR1 polymorphisms, especially in intron 1 region due to possibly promoter effects, with height variation and onset of menarche ${ }^{14-18)}$. Therefore, our hypothesis is that ESR1 can be a factor that controls the tempo of growth and puberty and a marker of CDGP.

In this study, at the rs827421 SNP locus in intron 1 of ESRI, we found the frequency of $G / G$ genotype was increased in CDGP patients. We thought that this means it may be a contributing factor of pubertal growth and a marker of CDGP. This is the first study about the association of ESR 1 with CDGP, but, there is a limitation that due to the relatively small number of cases and a difference of numbers between the case and control group. Further studies are required in a large population cohort.

\section{Conflict of interest}

No potential conflict of interest relevant to this article was reported.

\section{References}

1. Palmert MR, Hirschhorn JN. Genetic approaches to stature, pubertal timing, and other complex traits. Mol Genet Metab 2003;80:1-10.

2. Cousminer DL, Berry DJ, Timpson NJ, Ang W, Thiering E, Byrne EM, et al. Genome-wide association and longitudinal analyses reveal genetic loci linking pubertal height growth, pubertal timing and childhood adiposity. Hum Mol Genet 2013;22:2735-47.

3. Choi JH, Yoo HW. Control of puberty: genetics, endocrinology, and environment. Curr Opin Endocrinol Diabetes Obes 2013;20:62-8.

4. Gajdos ZK, Henderson KD, Hirschhorn JN, Palmert MR. Genetic determinants of pubertal timing in the general population. Mol Cell Endocrinol 2010;324:21-9.

5. Gajdos ZK, Hirschhorn JN, Palmert MR. What controls the timing of puberty? An update on progress from genetic investigation. Curr Opin Endocrinol Diabetes Obes 2009;16:16-24.

6. Banerjee I, Clayton P. The genetic basis for the timing of human puberty. J Neuroendocrinol 2007;19:831-8.

7. Harrington J, Palmert MR. Clinical review: distinguishing constitutional delay of growth and puberty from isolated hypogonadotropic hypogonadism: critical appraisal of available diagnostic tests. J Clin Endocrinol Metab 2012;97:3056-67.

8. Segal TY, Mehta A, Anazodo A, Hindmarsh PC, Dattani MT. Role of gonadotropin-releasing hormone and human chorionic gonadotropin stimulation tests in differentiating patients with hypogonadotropic hypogonadism from those with constitutional delay of growth and puberty. J Clin Endocrinol Metab 2009;94:780-5.

9. Kauschansky A, Dickerman Z, Phillip M, Weintrob N, Strich D. Use of GnRH agonist and human chorionic gonadotrophin tests for differentiating constitutional delayed puberty from gonadotrophin deficiency in boys. Clin Endocrinol (Oxf) 2002;56:603-7.

10. Nam HS, Shin MH, Kweon SS, Park KS, Sohn SJ, Rhee JA, et al. Association of estrogen receptor-alpha gene polymorphisms with bone mineral density in postmenopausal Korean women. J Bone Miner Metab 2005;23:84-9.

11. Lorentzon M, Lorentzon R, Backström T, Nordström P. Estrogen receptor gene polymorphism, but not estradiol levels, is related to bone density in healthy adolescent boys: a cross-sectional and longitudinal study. J Clin Endocrinol Metab 1999;84:4597-601.

12. Ding SL, Yu JC, Chen ST, Hsu GC, Hsu HM, Ho JY, et al. Diverse associations between ESR1 polymorphism and breast cancer development and progression. Clin Cancer Res 2010;16:3473-84.

13. Yaich L, Dupont WD, Cavener DR, Parl FF. Analysis of the PvuII restriction fragment-length polymorphism and exon structure of the estrogen receptor gene in breast cancer and 
peripheral blood. Cancer Res 1992;52:77-83.

14. Schuit SC, van Meurs JB, Bergink AP, van der Klift M, Fang Y, Leusink G, et al. Height in pre- and postmenopausal women is influenced by estrogen receptor alpha gene polymorphisms. J Clin Endocrinol Metab 2004;89:303-9.

15. Lei SF, Deng FY, Xiao SM, Chen XD, Deng HW. Association and haplotype analyses of the COL1A2 and ER-alpha gene polymorphisms with bone size and height in Chinese. Bone 2005;36:533-41.

16. Stavrou I, Zois C, Chatzikyriakidou A, Georgiou I, Tsatsoulis A. Combined estrogen receptor alpha and estrogen receptor beta genotypes influence the age of menarche. Hum Reprod 2006;21:554-7.

17. Long JR, Xu H, Zhao LJ, Liu PY, Shen H, Liu YJ, et al. The oestrogen receptor alpha gene is linked and/or associated with age of menarche in different ethnic groups. J Med Genet 2005;42:796-800.

18. Stavrou I, Zois C, Ioannidis JP, Tsatsoulis A. Association of polymorphisms of the oestrogen receptor alpha gene with the age of menarche. Hum Reprod 2002;17:1101-5.

19. van der Eerden BC, Karperien M, Wit JM. Systemic and local regulation of the growth plate. Endocr Rev 2003;24:782-801.

20. Korea Centers for Disease Control and Prevention (KCDC); Korean Pediatric Society, Committee for the Development of Growth Standard for Korean Children and Adolescents. 2007 Korean children and adolescents growth standard: commentary for the development of 2007 growth chart [Internet]. Cheongwon: KCDC, Division of Chronic Disease Surveillance; c2012 [cited 2012 Aug 30]. Available from: http://www.cdc.go.kr/ CDC/info/CdcKrInfo0201.jsp?menuIds=HOME001MNU0004-MNU0007-MNU0025\&fid=28\&q_type=\&q_ value $=\&$ cid $=1235 \&$ page $\mathrm{Num}=74$.

21. Greulich WW, Pyle SI. Radiographic atlas of skeletal development of the hand and wrist. 2nd ed. Stanford: Stanford Univ. Press, 1993.

22. Wehkalampi K, Widen E, Laine T, Palotie A, Dunkel L. Patterns of inheritance of constitutional delay of growth and puberty in families of adolescent girls and boys referred to specialist pediatric care. J Clin Endocrinol Metab 2008;93:723-8.

23. Banerjee I, Trueman JA, Hall CM, Price DA, Patel L, Whatmore AJ, et al. Phenotypic variation in constitutional delay of growth and puberty: relationship to specific leptin and leptin receptor gene polymorphisms. Eur J Endocrinol 2006;155:121-6.
24. Lin L, Conway GS, Hill NR, Dattani MT, Hindmarsh PC, Achermann JC. A homozygous R262Q mutation in the gonadotropin-releasing hormone receptor presenting as constitutional delay of growth and puberty with subsequent borderline oligospermia. J Clin Endocrinol Metab 2006;91:5117-21.

25. Sedlmeyer IL, Pearce CL, Trueman JA, Butler JL, Bersaglieri T, Read AP, et al. Determination of sequence variation and haplotype structure for the gonadotropin-releasing hormone $(\mathrm{GnRH})$ and $\mathrm{GnRH}$ receptor genes: investigation of role in pubertal timing. J Clin Endocrinol Metab 2005;90:1091-9.

26. Pugliese-Pires PN, Fortin JP, Arthur T, Latronico AC, Mendonca BB, Villares SM, et al. Novel inactivating mutations in the $\mathrm{GH}$ secretagogue receptor gene in patients with constitutional delay of growth and puberty. Eur J Endocrinol 2011;165:233-41.

27. Kauffman AS, Navarro VM, Kim J, Clifton DK, Steiner RA. Sex differences in the regulation of Kiss1/NKB neurons in juvenile mice: implications for the timing of puberty. Am J Physiol Endocrinol Metab 2009;297:E1212-21.

28. Seminara SB, Messager S, Chatzidaki EE, Thresher RR, Acierno JS Jr, Shagoury JK, et al. The GPR54 gene as a regulator of puberty. N Engl J Med 2003;349:1614-27.

29. Tommiska J, Wehkalampi K, Vaaralahti K, Laitinen EM, Raivio T, Dunkel L. LIN28B in constitutional delay of growth and puberty. J Clin Endocrinol Metab 2010;95:3063-6.

30. Ong KK, Elks CE, Wills AK, Wong A, Wareham NJ, Loos RJ, et al. Associations between the pubertal timing-related variant in LIN28B and BMI vary across the life course. J Clin Endocrinol Metab 2011;96:E125-9.

31. Gajdos ZK, Butler JL, Henderson KD, He C, Supelak PJ, Egyud M, et al. Association studies of common variants in 10 hypogonadotropic hypogonadism genes with age at menarche. J Clin Endocrinol Metab 2008;93:4290-8.

32. Vaaralahti K, Wehkalampi K, Tommiska J, Laitinen EM, Dunkel L, Raivio T. The role of gene defects underlying isolated hypogonadotropic hypogonadism in patients with constitutional delay of growth and puberty. Fertil Steril 2011;95:2756-8

33. Borjesson AE, Lagerquist MK, Liu C, Shao R, Windahl SH, Karlsson C, et al. The role of estrogen receptor $\alpha$ in growth plate cartilage for longitudinal bone growth. J Bone Miner Res 2010;25:2690-700. 